\title{
SUS 304 鋼焼鈍材の脱スケール過程における溶解挙動
}

\author{
木谷 滋*，林 美生*，小島寿男 ${ }^{* *}$, 日向寺幸夫**
}

\author{
Dissolution Behavior of Annealed SUS 304 Stainless Steel in Descaling Process
}

\author{
Shigeru KIYA*, Yoshio HAYASHI*, Toshio KOJIMA** and Yukio HYUGAJI**
}

\begin{abstract}
Analytical and electrochemical methods were used to study the dissolution behavior of annealed SUS 304 stainless steel in the descaling process in order to determine the annealing conditions needed to make scale easily descalable. The following conclusions are advanced :

(1) With anodic electrolysis in $20 \% \mathrm{Na}_{2} \mathrm{SO}_{4}$ solution ( $\mathrm{pH} 3$ ), oxides of $\mathrm{Cr}$, $\mathrm{Mn}$ and $\mathrm{Fe}$ in the outer layer of the scale are dissolved relatively quickly, but $\mathrm{Fe}$ in the inner layer is dissolved at a considerably low rate. The amount of dissolved $\mathrm{Fe}$ increases markedly at a potential above $1.4 \mathrm{~V}$ vs. SCE, which is nobler than that of $\mathrm{Cr}$ and $\mathrm{Mn}$ by $0.2 \sim$ 0.3V. Cathodic electrolysis is of no use in dissolving these oxides. Si oxide in the inner layer of the scale is not dissolved by electrolysis in $20 \% \mathrm{Na}_{2} \mathrm{SO}_{4}$ solution and obstructs the dissolution of other coexisting elements such as $\mathrm{Cr}$ and $\mathrm{Fe}$, but it is dissolved by immersion in nitric-hydrofluoric acid.

(2) To reduce the time required for descaling, it is important to lower the $\mathrm{Si}$ and Fe content in the scale and raise the $\mathrm{Cr}$ and $\mathrm{Mn}$ content, while making the scale thinner.
\end{abstract}

Key Words : Annealing, Descaling, Stainless Steel, Surface Analysis

\section{1. 緒言}

代表的オーステナイト系ステンレス鋼であるSUS 304 鋼薄板の工業生産において, 冷間圧延後の鋼帯は, 通常, 炭化水素ガスを燃料とする燃焼加熱炬で高温に加熱して 焼きなました後，表面に生成した酸化スケールを中性塩 電解法 ${ }^{1)}$ や硝フッ酸浸せき法によって連続的に除去し, 酸洗仕上げされる。筆者らは上記の連続焼鈍酸洗工程に おける脱スケール所要時間短縮を目的とし, 脱スケール の容易な酸化スケールを形成させるための焼鈍時の加熱

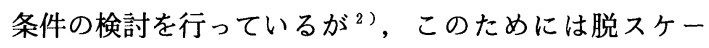
ル過程におけるスケールの溶解挙動を知ることが重要で ある。中性塩電解法によるステンレス鋼の酸化スケール の溶解挙動については, すでにいくつかの研究 ${ }^{3) ~ 6) ~ か ゙ ~}$ 報告されており, 脱スケールに伴うステンレス鋼表面の 変化や, 脱スケール処理条件の影響が明らかになりつつ

$*$ 住友金属工業㑣) 総合技術研究所（干314 茨城県鹿嶋市大字 光 3 番地)

Corp. Res. and Dev. Labs., Sumitomo Metal Ind., Ltd.

(3, Hikari, Kashima-shi, Ibaraki 314)

** 住友金属工業(侏) 鹿島製鉄所（干314 茨城県鹿嶋市大字光 3 番地)

Kashima Works, Sumitomo Metal Ind., Ltd. (3, Hikari, Kashima-shi, Ibaraki 314)
あるが，個々のスケール成分の溶解挙動については，か ならずしむ十分な解明がなされているとは言えない。ま た, 中性塩電解後の硝フッ酸浸せきを含めた全体の脱ス ケール過程における溶解機構解明も十分であるとは言え ない。

本研究では, SUS 304 鋼焼鈍材のスケール中の主要成 分である $\mathrm{Cr}, \mathrm{Mn}, \mathrm{Fe}, \mathrm{Si}$ の脱スケール過程における 溶解挙動解明を主目的として, 種々の表面分析や化学分 析手法および電気化学的手法を用いた調查を行った結果, 脱スケールを容易にするための焼鈍時の加熱条件やスケー ル組成に関して，新たな知見を得たので報告する。

\section{2. 実験方法}

\section{1 供試材}

表 1 に化学組成を示すオーステナイト系ステンレス鋼 SUS 304 の冷延鋼帯を 2 種類の燃焼加熱炉を用いて焼鈍 したあのを脱スケール試験の供試材（A 1 および A 2) とした。すなわち，A 1 は主として炉壁からの輻射熱に よって加熱するタイプの従来の燃焼加熱炉を用い, A 2 はバーナー炎を直接鋼板に噴射して急速加熱する夕イプ の直火式加熱炉を用いて焼鈍した。

Table 1 Chemical composition of SUS 304 stainless steels used (mass\%).

\begin{tabular}{|c|c|c|c|c|c|c|c|c|c|c|}
\hline Code & $\mathrm{C}$ & $\mathrm{Si}$ & $\mathrm{Mn}$ & $\mathrm{P}$ & $\mathrm{S}$ & $\mathrm{Cr}$ & $\mathrm{Ni}$ & $\mathrm{Mo}$ & $\mathrm{Cu}$ & Heating furnace \\
\hline $\mathrm{A} 1$ & 0.05 & 0.62 & 1.17 & 0.035 & 0.005 & 18.08 & 8.34 & 0.25 & 0.41 & Conventional type \\
\hline $\mathrm{A} 2$ & 0.07 & 0.44 & 1.18 & 0.034 & 0.007 & 18.53 & 8.51 & 0.24 & 0.26 & Direct flame type \\
\hline
\end{tabular}


Table 2 Methods, apparatus and conditions for analysis.

\begin{tabular}{|c|c|c|}
\hline Method & Apparatus & Condition \\
\hline $\begin{array}{l}\text { ICP Atomic emission } \\
\text { spectrometry }\end{array}$ & $\begin{array}{l}\text { SHI IMAZU/ } \\
\text { ICPS- } \\
\quad 1000 \text { II }\end{array}$ & $\begin{array}{l}\text { Frequency : } 27.12 \mathrm{MHz}, \quad \mathrm{RF} \text { power }: 1.2 \mathrm{~kW}, \\
\text { Observation height }: 15 \mathrm{~mm} \text { above the load coil, } \\
\text { Analytical lines : Fe( II ) } 259.837 \mathrm{~nm}, \mathrm{Cr} \text { ( II ) } 267.716 \mathrm{~nm} \text {, } \\
\mathrm{Mn} \text { ( II ) } 257.610 \mathrm{~nm}\end{array}$ \\
\hline $\begin{array}{l}\text { Secondary ion mass } \\
\text { spectrometry (SIMS) }\end{array}$ & $\begin{array}{l}\text { HITACHI/ } \\
\text { INA-3 }\end{array}$ & $\begin{array}{l}\text { Primary ion : }{ }^{28} \mathrm{~N}_{2}^{+} \text {, Acceleration voltage : } 15 \mathrm{kV} \text {, } \\
\text { Primary ion current }: 1 \times 10^{-7} \mathrm{~A} \text { (in Faraday Cup), } \\
\text { Secondary ions : }{ }^{16} 0^{+},{ }^{28} \mathrm{Si}^{+},{ }^{50} \mathrm{Cr}^{+},{ }^{5} \mathrm{Nn}^{+},{ }^{56} \mathrm{Fe}^{+},{ }^{60} \mathrm{Ni}^{+}\end{array}$ \\
\hline $\begin{array}{l}\text { X-ray photoelectron } \\
\text { mass spectroscopy } \\
\text { (XPS) }\end{array}$ & $\begin{array}{l}\text { VG/ } \\
\text { ESCALAB } \\
\text { YK II }\end{array}$ & $\begin{array}{l}\mathrm{X} \text {-ray : } \mathrm{Al} \mathrm{K} \alpha, 10 \mathrm{KV}, 20 \mathrm{~mA} \\
\text { Pass energy : } 20 \mathrm{eV} \\
\text { Reference peak }: \mathrm{Ag} 3 \mathrm{~d} 5 / 2=368.3 \mathrm{eV}\end{array}$ \\
\hline
\end{tabular}

\section{2 脱スケール方法}

$80^{\circ} \mathrm{C}, 20 \% \mathrm{Na}_{2} \mathrm{SO}_{4}$ （硫酸ナトリウム）水溶液中で の交番電解 (中性塩電解) を行った後に， $50^{\circ} \mathrm{C}, 8 \%$ $\mathrm{HNO}_{3}-0.7 \% \mathrm{HF}$ (硝フッ酸) 中へ浸せき(硝フッ酸浸せ き)することにより脱スケールした。なお，中性塩電解 に用いた $20 \% \mathrm{Na}_{2} \mathrm{SO}_{4}$ 水溶液は少量の硫酸を加えて $\mathrm{pH}$ を 3 に調節したものを用いた。電解電源としてポテンショ /ガルヴァノスタットまたは定電流直流電源と極性変換 装置の組み合わせを使用し，前者は後述の電解溶出試験 と電位測定に用い，後者は表面分析用試料作製と脱スケー ル試験に用いた。

\section{3 調查方法}

硫酸ナトリウム水溶液中での電解に伴うステンレス鋼 表面電位の変化を調べるとともに，液中に溶け出した金 属イオンの溶解量を ICP発光分光分析法によって求め た。また，脱スケール時間（脱スケール程度）の異なる 試験片を作り，表面を光学顕微鏡観察すると同時に，二 次イオン質量分析法 (SIMS) およびX線光電子分光分 析法（XPS）によって表面分析し，脱スヶールに伴う 表面組成などの変化を調べた。これらの分析法の分析条 件を表 2 に示す。

\section{3. 実験結果}

\section{1 中性塩電解時のスケール溶解挙動}

SUS 304 の焼鈍材 (A1) を $20 \% \mathrm{Na}_{2} \mathrm{SO}_{4}$ 水溶液 $(\mathrm{pH}$ $3,80^{\circ} \mathrm{C}$ ) 中で白金板を対極とし，ガルヴァノスタット により電流制御しながら交番電解 $\left(+800 \mathrm{~A} / \mathrm{m}^{2}, 2 \mathrm{~s}\right.$ $\rightarrow-800 \mathrm{~A} / \mathrm{m}^{2}, 1 \mathrm{~s}$ の繰り返し) または断続陽極電解 $\left(+800 \mathrm{~A} / \mathrm{m}^{2}, 2 \mathrm{~s} \rightarrow 0 \mathrm{~A} / \mathrm{m}^{2}, 1 \mathrm{~s}\right.$ の繰り返し $)$ する ことによって電解液中に溶出した $\mathrm{Cr}, \mathrm{Fe}, \mathrm{Mn}$ 濃度の 経時变化を図 1 に示す。スケール中の $\mathrm{Cr}$ や $\mathrm{Mn}$ の溶解 量は電解の初期に大きく増加し, その後の溶解速度は小 さいのに対して，Feの溶解速度は時間が経過してああ まり減少しなかった。また, $\mathrm{Cr}$ と $\mathrm{Mn}$ の溶解量は交番 電解之断続陽極電解でほとんど差が無く, Fe の溶解量

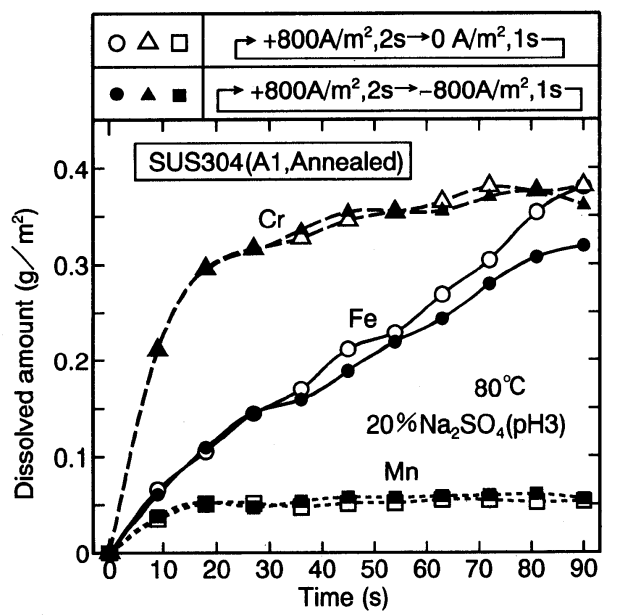

Fig. 1 Change of the amount of $\mathrm{Cr}, \mathrm{Mn}$ and $\mathrm{Fe}$ dissolved into $20 \% \mathrm{Na}_{2} \mathrm{SO}_{4}$ solution from annealed SUS 304 with electrolysis applying aquare wave current.

はむしろ交番電解の方が少ない傾向が認められた。これ より，これらの元素が陽極電解によって溶解し，陰極電 解は溶解に役立たないことが確かめられた。次に，上記 の試験と同様にして, $80^{\circ} \mathrm{C}, 20 \% \mathrm{Na}_{2} \mathrm{SO}_{4}$ 水溶液 $(\mathrm{pH} 3)$ 中で交番電解 $\left(+800 \mathrm{~A} / \mathrm{m}^{2}, 2 \mathrm{~s} \rightarrow 0 \mathrm{~A} / \mathrm{m}^{2}, 2 \mathrm{~s} \rightarrow-800\right.$ $\mathrm{A} / \mathrm{m}^{2}, 2 \mathrm{~s} \rightarrow 0 \mathrm{~A} / \mathrm{m}^{2}, 2 \mathrm{~s}$ の繰り返し)した場合の SUS 304 焼鈍材 (A1) の電位の変化を図 2 に示す。電流 密度 $800 \mathrm{~A} / \mathrm{m}^{2}$ での陽極電解時の電位はおよそ $+1.7 \mathrm{~V}$ (vs. SCE)，陰極電解時の電位はおよそ-1.7V (vs. $\mathrm{SCE}$ )であり，これを図1の結果および Pourbaix の 電位 $-\mathrm{pH} \mathrm{W}^{7)}$ と考え合わせると，スケール中の $\mathrm{Cr}$, $\mathrm{Mn}$ および $\mathrm{Fe}$ は陽極電解時に高原子価の $\mathrm{Cr}_{2} \mathrm{O}_{7}{ }^{2-}$, $\mathrm{MnO}_{4}{ }^{-}$および $\mathrm{FeO}_{4}{ }^{2-}$ イオンとして溶解する可能性が ある。ただし，これらのイオンの内， $\mathrm{Cr}_{2} \mathrm{O}_{7}{ }^{2-}$ が生成 することは知られているが ${ }^{3)}$ ，4，他の 2 つの生成は確 認されていない。また, 図 3 は同じ試料を同じ電解液中 でポテンショスタットにより 30 秒間定電位電解した場 


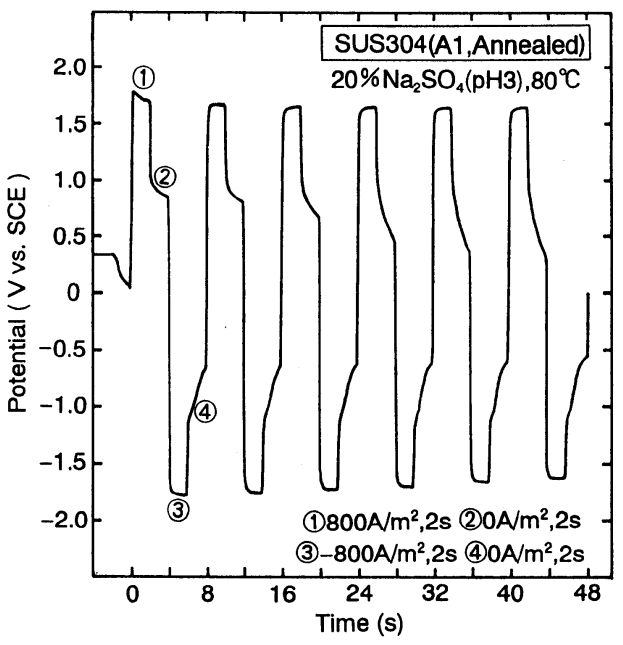

Fig. 2 Change of the potential with alternating current square wave, $+800 \mathrm{~A} / \mathrm{m}^{2}(2 \mathrm{~s}) \rightarrow 0 \mathrm{~A} / \mathrm{m}^{2}(2 \mathrm{~s}) \rightarrow$ $-800 \mathrm{~A} / \mathrm{m}^{2}(2 \mathrm{~s}) \rightarrow 0 \mathrm{~A} / \mathrm{m}^{2}(2 \mathrm{~s})$, applied to annealed SUS 304 .

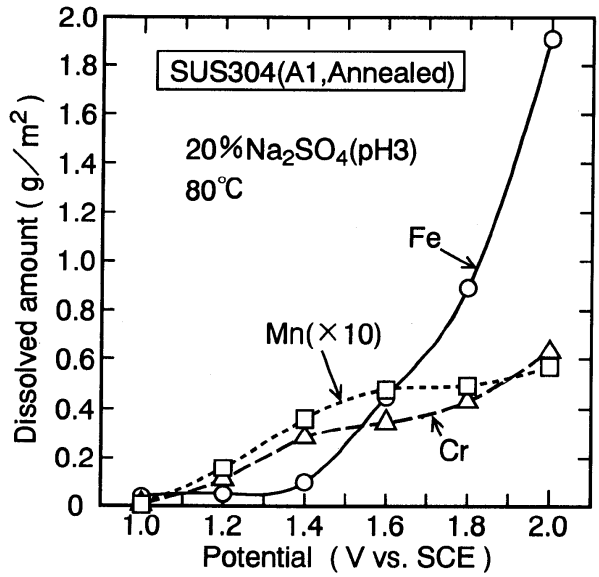

Fig. 3 Effect of the potential on the amount of $\mathrm{Cr}, \mathrm{Mn}$ and $\mathrm{Fe}$ dissolved into $20 \% \mathrm{Na}_{2} \mathrm{SO}_{4}$ solution from annealed SUS 304 by the anodic electrolysis for $30 \mathrm{~s}$.

合の溶出金属濃度と設定電位との関係を示している。 $\mathrm{Cr}$ と $\mathrm{Mn}$ は1.1〜1.2V(vs. SCE) より貴の電位で溶解 量が増加するが，Feは1.4V（vs. SCE）より貴の電位で 溶解が進む。

\section{2 脱スケール過程での表面の変化}

SUS 304 の焼鈍材およびこれらの脱スケール過程に おける表面を SIMS で調べた結果（成分元素の深さ方向 の濃度プロフィール）を図 4 に示す。2 種類の SUS 304 焼鈍材（A1，A2）の焼鈍ままの表面には，いずれも最 表面に $\mathrm{Mn}$ および $\mathrm{Fe}$ の小さなピークがあり，その少し 内側に $\mathrm{Cr}$ のピーク，さらに内側に幅広い $\mathrm{Si}$ のピーク が認められる。一方，Ni は母材部より表面濃度が低下

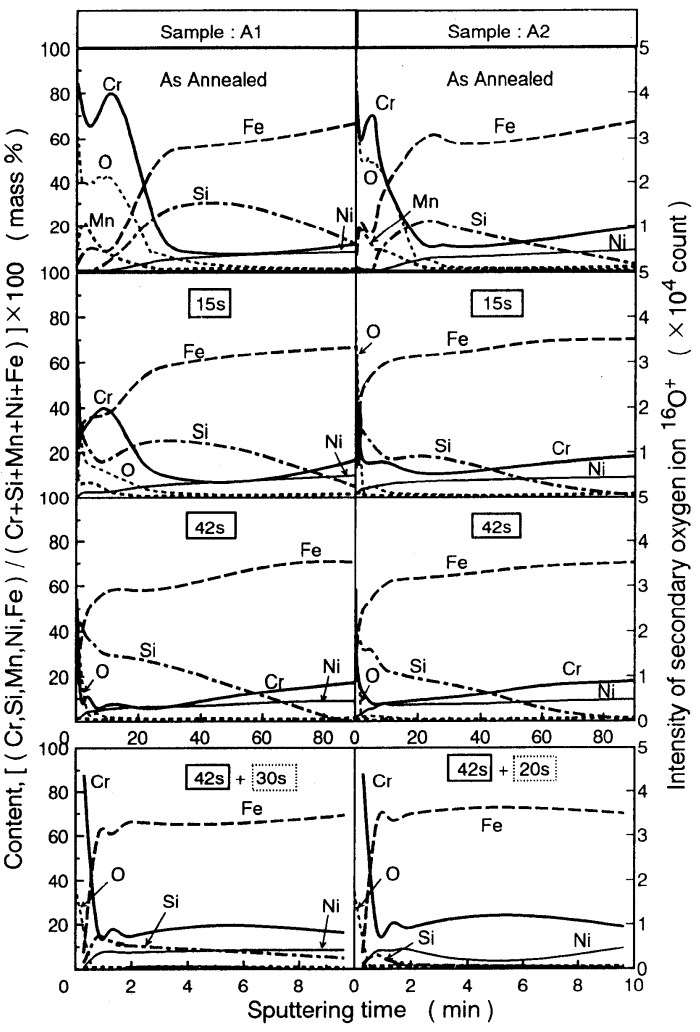

Fig. 4 Elemental concentration profiles by SIMS in the near surface region of two SUS 304 stainless steels annealed or additionally pickled (The figures enclosed by a rectangular solid line or a rectangular dotted line shows the period for the electrolysis in $20 \% \mathrm{Na}_{2} \mathrm{SO}_{4}$ solution or for the immersion in $8 \% \mathrm{HNO}_{3}-0.7 \% \mathrm{HF}$ solution, respectively).

している。表面濃化元素の内, $\mathrm{Mn}, \mathrm{Cr}$ および $\mathrm{Si}$ のピー クは明らかにA2 より A1 の方が幅が広く（高さも高い）, これらの元素が表面付近により多く濃化していることが うかがえる。また，酸素のイオン強度のプロフィールか らも，A1の方が $\mathrm{A} 2$ 上り表面酸化物首（スケール）が 厚いことが推定される。そして，これらの焼鈍材を 20 $\% \mathrm{Na}_{2} \mathrm{SO}_{4}$ 水溶液 $\left(\mathrm{pH} 3,80^{\circ} \mathrm{C}\right)$ 中で交番電解 $(+800$ $\mathrm{A} / \mathrm{m}^{2}, 2 \mathrm{~s} \rightarrow-800 \mathrm{~A} / \mathrm{m}^{2}$ ，1s の繰り返し）すること により, 表面付近の $\mathrm{Cr}$ や $\mathrm{Mn}$ のピークは小さくなり, $42 \mathrm{~s}$ 後には完全に消失し, 最表面には Si 濃化層が現れ た。この Si 濃化層は中性塩電解では溶解せず，続いて 行われた硝フッ酸浸せき処理によって溶解した。ただし， 焼鈍材 $\mathrm{A} 1$ （従来の燃焼加熱炬使用）之 $\mathrm{A} 2$ （直火式加熱 炉使用）を比較すると， A2 が $15 \mathrm{~s}$ の中性塩電解によっ て Crのピークがほとんど消失したのに対して，A1 は 残存し, 硝フッ酸浸せき後の Si 濃化層の残存屯多かっ た。次に, $20 \% \mathrm{Na}_{2} \mathrm{SO}_{4}$ 水溶液 $\left(\mathrm{pH} 3,80^{\circ} \mathrm{C}\right)$ 中で交番 電解 $\left(+800 \mathrm{~A} / \mathrm{m}^{2}, 2 \mathrm{~s} \rightarrow-800 \mathrm{~A} / \mathrm{m}^{2}, 1 \mathrm{~s}\right.$ の繰り返し) 
した後, 電解時間の半分の時間だけ $50^{\circ} \mathrm{C}, 8 \% \mathrm{HNO}_{3}$ $0.7 \% \mathrm{HF}$ に浸せきする方法で $\mathrm{A} 1$ と 2 をを脱スケールし， 光学顕微鏡観察でスケール残存が認められなくなるのに 要する時間（脱スケール時間）を調べたところ，A1が 85.5 90s, A2 が56s（各 3 回実験）であった。図 5 は 溶解過程における酸化物の状態をXPSによって追跡し た結果であるが，これより焼鈍ままの表面では $\mathrm{Fe}$ は酸 化物の形で存在するが, 中性塩電解による溶解が進むに つれて金属状態のものが多くなり，硝フッ酸浸せき後は 金属がさらに多くなることがわかった。また，中性塩電 解 $15 \mathrm{~s}$ 後の表面からは $\mathrm{SiO}_{2}$ が明瞭に検出されたが，こ れは図 4 の SIMS 分析結果と整合する。

\section{4. 考察}

中性塩電解による SUS 304 焼鈍材表面の構成元素の 溶解速度について考えると，図 1 と図 3 の溶解量の実測

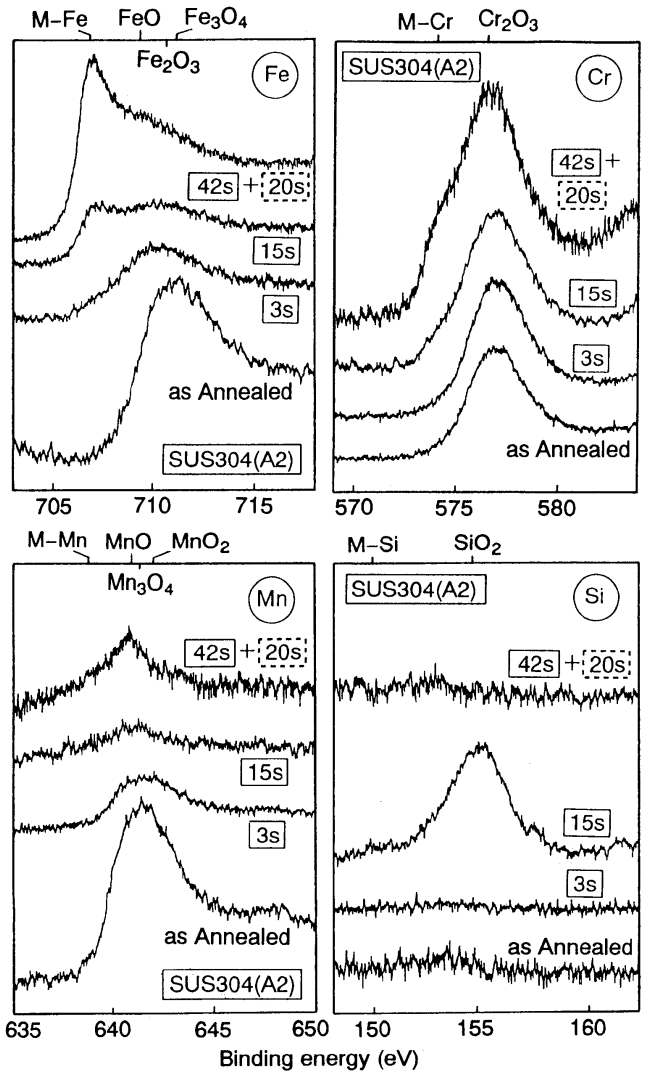

Fig. 5 Spectrograms for $\mathrm{Fe}, \mathrm{Cr}, \mathrm{Mn}$ and Si by XPS surface analysis of a SUS 304 stainless steel annealed or additionally pickled, where the figures enclosed by a rectangular solid line or a rectangular dotted line shows the period for the electrolysis in $20 \% \mathrm{Na}_{2} \mathrm{SO}_{4}$ solution or for the immersion in $8 \% \mathrm{HNO}_{3}-0.7 \% \mathrm{HF}$ solution, respectively.
データおよび図 4 の焼鈍まま材の濃度プロフィールより， 外層スケール中の $\mathrm{Cr}$ や Mn 酸化物の溶解速度はかなり 速いものと推測される。また，スケール外層中の Fe 酸 化物の溶解速度むかなり速いようであるが，これは溶解 しやすい Crや Mn 酸化物之共存するためでああると推 測される。そして，Feは表面から内側へ入るにつれて 含有率が高くなるにあかかわらず溶解速度はほとんど大 きくならない。この理由としては，表面から内側へ入る につれて, (1) Cr と Mnの含有率が減少し, 中性塩電解 では溶解しないSi の含有率が増加する, (2) 酸素含有率 が低くなり，より金属に近い状態の Feが増加する，こ とが考えられる。以上をまとめると，中性塩電解で溶解 しやすい SUS 304 焼鈍材のスケール組成は Cr と Mn 酸 化物の濃度が高く, Si と Feの濃度が低いあのであると 推测される。

次に, SUS 304 鋼の加熱条件とスケール組成および 脱スケール性の関係について考察する。SUS 304 冷延 材の焼鈍過程で生成する酸化スケールの組成は加熱温度 によって大きく異なる ${ }^{2)}$ 。すなわち，スケール中の $\mathrm{Cr}$ と Mn は SUS 304 の焼鈍温度付近（1100 $1150^{\circ} \mathrm{C）で}$ 加熱された場合に最も濃化するが，Si はこれより低温 の $900 \sim 1000^{\circ} \mathrm{C}$ で最む濃化し， Si と Cr の濃度比は 800 ${ }^{\circ} \mathrm{C}$ 前後で最大となる。従って，焼鈍温度への昇温に要す

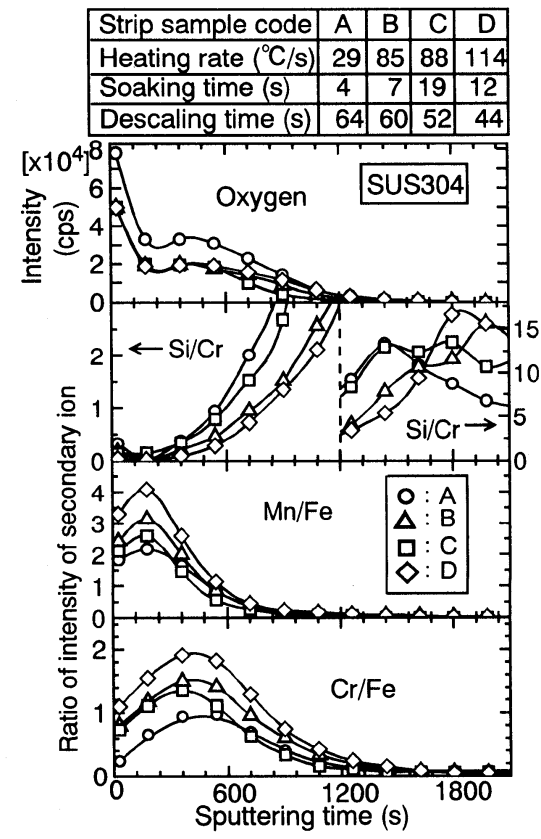

Fig. 6 Relation among the heating conditions (heating rate over a temperature range from $400^{\circ} \mathrm{C}$ to $900^{\circ} \mathrm{C}$, and soaking time at a temperature above $1000{ }^{\circ} \mathrm{C}$ ), the composition of the scale analyzed by SIMS and the time required for descaling. 
る時間をなるべく短縮（急速加熱）した後, 焼鈍温度で 保持することにより, Si と Cr の濃度比の小さいスケー ルが生成し, 中性塩電解で溶けやすくなることが推測さ れる。

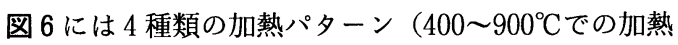
速度と $1000^{\circ} \mathrm{C}$ 以上での均熱時間を図上部の枠内に表示） で焼鈍した SUS 304 のスケール組成（SIMSによるイ オン強度比またはイオン強度の深さ方向分布）之脱スケー ル所要時間（前記の3.2で述べたものと同じ脱スケール 条件で求めた值を図上部の枠内に表示）の関係 ${ }^{2)}$ を示 している。酸素イオン強度のプロフィールより, 4 種類 の焼鈍材のスケール厚さにはあまり差が無く, $\mathrm{Cr} / \mathrm{Fe}$ 比と $\mathrm{Mn} / \mathrm{Fe}$ 比が大きく, $\mathrm{Si} / \mathrm{Cr}$ 比が小さい（Cr と $\mathrm{Mn}$ 濃度が高く, Fe と Si 濃度が低い）あのほど脱スケール 時間が短いこと, およびこのためには加熱速度が速く, 均熱時間を $10 \mathrm{~s}$ 以上とすることが重要であることがわか る。ただし, 均熱時間が長すぎる場合には, スケール 外層中の Crや Mn の濃度が高まって中性塩電解で溶解 しやすい組成にはなるが, スケール（特に, Si の濃化 したスケール内層）が厚くなるために硝フッ酸浸せきを 含めた全体の脱スケール時間は長くなる。

以上の実験および考察の結果を，スケール組成および 厚さと脱スケール性の関係についてまとめると, スケー ル外層中の $\mathrm{Si}$ や $\mathrm{Fe}$ 濃度が低く, $\mathrm{Cr}$ や $\mathrm{Mn}$ 濃度が高い ことと, スケール（外層および Si 濃化層）が薄いこと が SUS 304 焼鈍材の脱スケール所要時間を短くするた めに有効である。

\section{5. 結言}

SUS 304 鋼焼鈍材のスケール中の主要成分である Cr, $\mathrm{Mn}, \mathrm{Fe}$ および $\mathrm{Si}$ の脱スケール過程における溶解挙動 を調べた結果，以下のことが明らかになった。

（1）中性塩電解脱スケールにおいて，スケール外層に多 く含まれる Cr および Mnの酸化物は, 比較的短時間の 電解で大部分が溶解する。また, 外層に含まれる $\mathrm{Fe} の$ 酸化物も比較的容易に溶解するが, 表面から内側へ入る につれて溶解し難くなる。これは, スケール内層では,
$\mathrm{Cr}, \mathrm{Mn}$ の濃度が低くなり, 中性塩電解で溶解しない Si の濃度が高くなると同時に, より金属状態に近い $\mathrm{Fe}$ が増えるためと推測される。

（2）スケール中の $\mathrm{Cr}, \mathrm{Mn}$ および $\mathrm{Fe}$ は中性塩電解の陽 極電解時に溶解するものと推定される。また, $\mathrm{Cr}$ と $\mathrm{Mn}$ は 1.2V(vs. SCE) より貴の電位で溶解速度が速ま るが，Feは1.4V(vs. SCE) より貴の電位で溶解が進む。 （3）中性塩電解後に硝フッ酸浸せきすることにより，中 性塩電解で溶解しなかった内層の Si 濃化層が溶解する。 従って, Si 濃化層が厚いほど, 硝フッ酸による脱スケー ルに長時間を要する。

以上のスケール成分の溶解挙動より, 脱スケール時間 短縮のためにはスケール外層中の $\mathrm{Si}, \mathrm{Fe}$ 濃度を低め, $\mathrm{Cr}, \mathrm{Mn}$ 濃度を高めると同時に, スケール（外層および $\mathrm{Si}$ 濃化層）厚さを薄くする焼鈍条件が望ましい。

\section{謝 辞}

本研究のため表面分析をしていただいた住友金属テク ノロジー(侏殿，焼鈍材の製作に協力していただいた三菱 重工業侏広島研究所殿, 研究の推進および論文の執筆に あたり貴重な御助言をいただいた住友金属工業(株)諸石大 司博士, 渋谷敦義博士, 津田哲明博士, ならびに中性塩 電解液の分析をしていただいた住友金属工業(株)直江津製 造所黒田貞夫殿, 高橋勝巳殿に厚く御礼申し上げます。

(Received November 24, 1995 ; Accepted January 17, 1996)

\section{文献}

1）フリードリッヒ マチニー；特公昭38-12162（1963）

2 ）木谷 滋, 林 美生, 小島寿男, 日向寺幸夫 ; 鉄と鋼, 81, 1007 (1995)

3 ) 秦 和宣, 山口輝雄, 丹野和夫, 古谷保正 ; 日立評論, 58 , 7 (1976)

4 ) 古谷保正, 丹野和夫; 電気化学, 45, 252 (1977)

5 ) 蓮野貞夫, 石川正明, 村林 実, 山口裕弘, 椎葉末信, 塩 川 隆; 川崎製鉄技報，23，29（1991）

6 ）松橋 亮, 伊藤 䟾, 中田朝雄, 及川雄介, 大村圭一; 材 料之環境, 42, 576 (1993)

7) P. Pourbaix ; Atlas of Electrochemical Equilibria, p. 286 463 (Pergamon Press, 1966) 